\title{
Patent Law and Its Enforcement in Indonesia, Japan and the USA
}

\section{Endang Purwaningsih}

Faculty of Law, University of YARSI Jakarta, Indonesia. E-mail: e.purwaningsih@yarsi.ac.id

\begin{tabular}{l} 
ARTICLE INFO \\
\hline Keywords: \\
comparative study; law \\
enforcement; patent \\
protection \\
How to cite: \\
Purwaningsih, E. (2020). \\
Patent Law and Its \\
Enforcement in Indonesia, \\
Japan, and USA. JURNAL \\
MEDIA HUKUM, 27(1), \\
1-22. \\
Article History: \\
Received: 15-08-2019 \\
Reviewed: 21-02-2020 \\
Revised: 02-03-2020 \\
Accepted: 24-06-2020
\end{tabular}

\begin{abstract}
The fundamental issues in the era of industrialization is the protection of patent rights and the enforcement of the patent law. In Indonesia, Intellectual Property Rights (IPR) including patent tend to be violated with regard to foreign investment and transfer of technology issue. Therefore, as a member of the WTO, it is necessary for Indonesia to learn from other countries such as Japan and the United States of America, especially in terms of regulations. The purpose of this study is to find out the fundamental differences among Indonesia, Japan and America regarding the protection of patent rights and the enforcement of patent law. This research is a normative legal research. Data is collected from books, international journals, relevant laws and government regulations. The results show that the scope of patent protection in Japan, the United States and Indonesia has so far followed TRIPS and WTO provisions. Basically, Indonesia, Japan, and America have the same acquisition system, namely "first to file". Historically before 2013 America has ever used "first to invent" system. Coverage of protection remains the same in the fields of technology and industry, but Japan extends the scope of patents to cover those produced by the employees and Indonesia also adopts this model. In term of enforcement, Indonesian patent law also develops a new appeal commission to settle patent disputes.
\end{abstract}

\section{DOI: $10.18196 /$ jmh. 20200138}

Copyright (C) 2020 JURNAL MEDIA HUKUM. All rights reserved.

\section{Introduction}

Intellectual property/IP owned by the inventor or creator gives birth to Intellectual Property Rights (IPR) which should be protected and exploited in accordance with the rule of law. Although the principle of IPR comes from developed countries, but inevitably developing countries follow it because of the attachment to the World Trade Organization (WTO) namely Trade-Related Aspects of Intellectual Property Rights (TRIPs) and Trade-Related Investment Measures (TRIMs). For corporations, Integrated Circuits (IC) is an asset according to Emanuel1, "corporate assets consist not only of

\footnotetext{
1 Emanuel, S. L. (2013). Corporations and Other Business Entities. Wolters Kluwer Law \& Business, p. 220.
} 
tangible goods but also intangibles like information". Barnes, Dworkin \& Richards ${ }^{2}$ also assert that, "there are intangible and tangible property. Tangible property has a physical existence; property that has no physical existence is called intangible property: Patents rights, easements, and bonds are examples of tangible property."

"The protection system for Intellectual Property Rights is basically territorial in which registration and enforcement of the law must be carried out separately in each relevant jurisdiction in a particular region or country." In ASEAN, protection of intellectual property is very minimal, especially the brand regime where this can be a serious challenge for developing countries like in ASEAN. In practice, even well-known trademarks are often used without permission and registered by irresponsible parties. In this case, "Protocol Madrid can be used to realize more effective legal protection for intellectual property rights like well-known brands in ASEAN." ${ }^{3}$

A study of the mythology of common copyright law reveals that the revolution in intellectual property rights does not see the future, but looks back, and that does not fit the purpose of the Patent and copyright clauses. As is common law copyright theory, which deliberately conceptualizes social relations to rearrange as a property for centuries. "Common law copyright mythology shows that this conceptualization has worked well historically so as to be able to push the law towards as if it was centered on the writer but actually focused on the rights of intermediaries." 4

The passage of legislation in the field of IP is very challenging, especially in the field of Patents for theorists and researchers who want to understand the extent of its scope/scope, as well as its application, whether its scope and enforcement are relevant to the goal of improving Indonesian science and technology, and how the actual legislation in developed countries such as developed countries like Japan and America, do they always revise the rule of law for the advancement of science and technology. Aplin and Davis ${ }^{5}$ stated that, "To be Patentable, an invention must feature an inventive step. The inventive step inquiry asks whether the invention is obvious to a person skilled in the art, having regard to what forms part of the state of the art."

Like other ownership rights, intellectual property rights are relationships between individuals. Unlike real property law, intellectual property law places rights in an object. Algorithms and formulas for a treatment and its descent are examples of abstract objects. Some of them are related to needs, uses and depend on such objects. Many interrelated relationships that characterize social life, especially in modern society and the technological era as it is today. Some reasons why intellectual property is like a property, among others: a) the form of property allows private hands to capture important abstract objects, b) creates many relationships that depend on

\footnotetext{
2 Barnes et al. (2012). Law for Business. Mc.Graw Hill Irwin, p. 644.

3 Rohaini. (2018). The Madrid Protocol: Mewujudkan Perlindungan Hukum yang Efektif bagi Merek Terkenal di ASEAN. Jurnal Media Hukum, 25(1), p. 70.

4 O'Melinn, L. (2015). Property without Bounds and the Mythology of Common Law Copyright, Special Issues: Thinking and Rethinking Intellectual Property, Studies in Law, Politics and Society. Emerald Group Publishing Limited, 67, p. 75. https:// doi.org/10.1108/S1059-433720150000067004

${ }^{5}$ Aplin, T. \& Davis, J. (2013). Intellectual Property Law, Text, Cases and Materials (2nd ed.). Oxford University Press., p. 685.
} 
people in society, c) foster personal power such as new innovations, d) individual freedom where the right not to be disturbed, and e) facing for greater danger6.

Computerized technology-based systems, methods and media are provided to support the analysis of intellectual property documents by linking and explaining patents, copyrights, trademarks, licensing agreements, and other types of intellectual property documents. Lee \& Mei's findings explain that the use of computerized technology can help professionals and governments with regard to intellectual property to commemorate their thinking processes, work products, and reasoning, in their initial or final form, and will be more flexible to support the development and use of related sets intellectual property relations. ${ }^{7}$ In other words, protection and law enforcement of intellectual property must also include the development of science and technology to be more effective.

Firdausy ${ }^{8}$ explained that the development of science and technology now and in the future cannot be done through shortcuts or only through policy alone, even though it certainly is not a government monopoly. Going forward, the role of the government should no longer rely solely on policies that are indirect (such as macroeconomic and trade stability policies) but it is time to make direct policies such as purchasing policies on domestic science and technology products, provision of Micro, Small, and Medium Enterprise (MSME) science and technology and science and technology education and training since age early. Likewise, according to Lakitan', the need to reorient the development of technology must be more inward oriented. The domestic market is a large market and is being flooded with foreign technology products.

For example, one of the technological developments currently being developed is the use of block chain technology which is claimed to be one of the revolutionary technologies that have a huge impact on life. The opportunities offered by block chain are very potential with respect to the future of IP law and the potential impact on registration, management and enforcement of intellectual property rights. ${ }^{10}$

In addition, Daulay explained that the government as a developing country that has a heritage of traditional knowledge and cultural diversity should have the maximum legal regulatory practice by applying the concepts of defensive and positive protection involving intellectual property regimes such as patents, trademarks, and geographical indications. ${ }^{11}$

Japan and America are chosen to represent developed countries that dominate Patents (the world's largest Patent registrants), and on the other hand Indonesia as a developing country which for decades has been a 'colony' of their technology, even

\footnotetext{
6 Drahos, P. (2016). A Philosophy of Intellectual Property (1st ed.). The Australian National University, Canberra. https://doi.org/10.4324/9781315263786

7 Lee, E. M. \& May, D. C. (2016). Computer Assisted and/or Implemented Process and System for Annotating and/or Linking Documents and Data, Optionally in an Intellectual Property Management System. United States Patent, 9.460.414, p. 1-45. https:// patents.google.com/patent/US9460414B2/en

8 Firdausy, C. M. (2009). Iptek Tidak Hanya di Tangan Pemimpin. In Sain dan Teknologi. PT Gramedia Pustaka Utama, p. 185.

${ }^{9}$ Lakitan, B. (2009). Teknologi Berorientasi Domestik. In Sain dan Teknologi. PT Gramedia Pustaka Utama, p. 181.

10 Gürkaynak et al. (2018). Intellectual Property Law and Practice in the Block Chain Realm. Computer Law E Security Review, 34(4), p. 847. https://doi.org/10.1016/j.clsr.2018.05.027

11 Daulay, Z. (2012). Konsep Perlindungan Hukum terhadap Pengetahuan Tradisional Masyarakat Asli Tentang Obat di Indonesia. Jurnal Media Hukum, 19(2), p. 181.
} 
with the issue of technology transfer, developed country products dominate the Indonesian market share, Indonesian people become consumers and operators. Both the Japanese, American and Indonesian Patent Laws have been revised and the latest revision took effect since 2016, so it is necessary to be studied more deeply.

"Modern intellectual property law includes not only the rules governing the existence and extent of rights such as the regulations on the validity and infringement of Patents, copyrights and trademarks. But it is also a doctrine to regulate trade in goods that embodies IP rights. Such commercial law covers all the sub-fields in IP law. "In the last few decades there has been rapid development because intellectual property has become economically valuable and because of the revolutionary right to create and use more nuanced licensing agreements. ${ }^{12}$

With so many Patents, it is very useful for society and the state in promoting technological and economic growth. According to Gibbs \& Dematties ${ }^{13}$ with a Patent it can market share increase, strengthen competitive position, reduce production costs, expand product line, invest in already proven product, and leverage your small internal engineering group. The problem of this research is about (1) the scope of Patent protection according to existing Patent Law in Japan, America and Indonesia and (2) the enforcement of Patent law in Positive Patent law in Japan, America and Indonesia. The formulation of the problem is at once a limitation in the scope of the research to be conducted.

The novelty of this research, namely 1) is able to map out the fundamental differences in the application of law both in Indonesia, Japan, and the United States, which have different Patent rezim. Japan and America are chosen to represent developed countries that dominate Patents (the world's largest Patent registrants), and on the other hand Indonesia as a developing country which for decades has been the 'colony' of their technology. 2) originality of this research is also expected to be able to answer the benefits of technology transfer issues. It is because the issue of technology transfer turned out to only fool the Indonesian people. So, developed country products dominate the Indonesian market share and therefore Indonesian people became consumers and operators. 3) the originality of this study was also able to provide the latest answers after the Japanese, American and Indonesian Patent Laws were revised and the latest revision took effect since 2016. In short, it is necessary to be studied more deeply.

\section{Method}

\subsection{Type of Research}

This research is a normative legal research. The success of legal research depends on the quality of research topic. Researchers will easily carry out legal research when the topic chosen is in accordance with the researcher's interest in the field of law that will be developed. Another consideration is the availability of legal sources and whether the topic chosen has not been studied by other researchers before ${ }^{14}$. Legal research is

\footnotetext{
12 Duffy, J. F., \& Hynes, R. (2016), Statutory Domain and the Commercial Law of Intelectual Property, Virginia Law Review, 102(1), p. 1. https://papers.ssrn.com/sol3/papers.cfm?abstract_id=2599074.

${ }^{13}$ Gibbs, A. \& DeMatteis, B. (2003). Essentials of Patents, John Wiley \& Sons, Inc, p. 33-35

14 Susanti, D.O. \& Efendi, A. (2005). Penelitian Hukum (Legal Research)(2nd ed.). Sinar Grafika, p. 23.
} 
conducted to find out solutions to legal issues that arise, therefore legal research is a study within the framework of how to understand law- The result is to provide a prescription of what should be the issue and how to overcome the problems. ${ }^{15}$

\subsection{Data Collection}

Since the research is a normative legal research, the data used is secondary data by examining the principles of law, laws both from various legal sources in Indonesia, Japan and America; and elements related to the object of research such as from reputable international journals, official sources from the offices of the authorities handling Patents in the three relevant countries.

\subsection{Data Analysis}

Documentation and qualitative data were analyzed using four stages: data collection, data classification, data reduction, and finally conclusions. The analytical method used in this study is a comparative approach by comparing: a) the scope of Patent protection according to Patent Law in Indonesia, Japan, and America, b) the qualification requirements for Patentability invention, c) the acquisition system, and d) the scope of protection.

\section{Analysis and Results}

\subsection{Scope of Patent Provisions according to Patent Law in Indonesia, Japan, America}

\subsubsection{In Indonesia}

It is indeed mentioned in the explanation of Law Number 13 of 2016 concerning Patents (Patent Law), that the revised approach to the Patent Law is aimed at optimizing the presence of the state in the best service of the government in the field of Intellectual Property; alignments with Indonesia's interests without violating international principles; realizing economic independence by moving the strategic sectors of the domestic economy by encouraging national inventions in technology to realize technological strengthening; and building the foundation of the National Patent through a systemic approach to pragmatic legal realism. But it should be noted that the benefit of the implementation of the Patent itself, apart from the economic, social aspects, also stimulates the growth of motivation to increase advanced technology and increasingly competitive competition, so that in addition to definite regulations, a more concise and efficient registration procedure is certainly desirable.

Meanwhile, to explore how the ability to benefit can be realized either for commercial purposes or to create competitive advantage, a number of disclosure strategies can be carried out, among others, by maintaining confidentiality, Patents and open science (scientific publications). ${ }^{16}$ Patent protection in Indonesia continues to adjust to the dynamics of domestic technological and industrial interests, even though it later feels forced when there are articles in Article 20 of the Patent Law. Article 20 of the Patent Law states: 1) Patent Holders are required to make products or use processes in Indonesia, and 2) Making a product or using the process referred to in paragraph (1) must support technology transfer, investment absorption and/or employment.

\footnotetext{
${ }^{15}$ Marzuki, P.M. (2007). Penelitian Hukum. Kencana, p. 41.

16 Gans et al. (2017), Contracting Over the Disclosure of Scientific Knowledge: Intellectual Property and Academic Publication. Research Policy, 46(4), p. 820. https://doi.org/10.1016/j.respol.2017.02.005
} 
Patent holders are required to make products or use processes in Indonesia. This may happen if Indonesia has prepared everything to be conducive to the growth of domestic technology and industry, by deviating the provisions of TRIPs, in order to advance domestic technology growth. It is believed that the sentence should be: Patent Holders are required to use patented products or processes in Indonesia and in other countries where Patents are also registered. The sentence "Making a product or using the process as referred to in Paragraph (1) must support the transfer of technology, absorption of investment and/or providing employment". This reminds that in the era of 60-70, it was a well-known issue of technology transfer but then there was a tie in clause which forced companies operating licensing in Indonesia to use raw materials and experts/assistance from the licensor (foreign company).

Article 7 states that "TRIPS Agreement (The protection and enforcement of intellectual property rights should contribute to the promotion of technological innovation and to the transfer and dissemination of technology, to the mutual advantage of producers and users of technological knowledge and in a manner conducive to social and economic welfare, and to a balance of rights and obligations) indeed it is mentioned that the protection and enforcement of intellectual property rights must contribute to the promotion of technological innovation and the transfer and dissemination of technology, for the mutual benefit of technology producers and users, then Article 27: TRIPS Agreement-Patentable Subject Matter:

1. Subject to the provisions of paragraphs 2 and 3, Patents shall be available for any inventions, whether products or processes, in all fields of technology, provided that they are new, involve an inventive step and are capable of industrial application. Subject to paragraph 4 of Article 65, paragraph 8 of Article 70 and paragraph 3 of this Article, Patents shall be available and Patent rights enjoyable without discrimination as to the place of invention, the field of technology and whether products are imported or locally produced.

2. Members may exclude from Patentability inventions, the prevention within their territory of the commercial exploitation of which is necessary to protect ordre public or morality, including to protect human, animal or plant life or health or to avoid serious prejudice to the environment, provided that such exclusion is not made merely because the exploitation is prohibited by their law.

3. Members may also exclude from Patentability:

(a) diagnostic, therapeutic and surgical methods for the treatment of humans or animals;

(b) plants and animals other than micro-organisms, and essentially biological processes for the production of plants or animals other than non-biological and microbiological processes. However, Members shall provide for the protection of plant varieties either by Patents or by an effective sui generis system or by any combination thereof. The provisions of this subparagraph shall be reviewed four years after the date of entry into force of the WTO Agreement.

Patents granted are prohibited from discrimination against the place of discovery in the field of technology whether the product is imported or produced locally. So the articles related to Article 4 (Patent subject eligibility), Article 20 (domestic manufacturing requirements), Article 78 (commercial license agreement for intellectual property rights) and Articles 82-120 (regarding compulsory licensing), need to be reexamined as to the effect Indonesia's technology and economy, as well as the interests of foreign investors which of course must bring benefits to Indonesia. 


\section{Article 28 Rights also conferred that:}

1. A Patent shall confer on its owner the following exclusive rights:

(a) where the subject matter of a Patent is a product, to prevent third parties not having the owner's consent from the acts of: making, using, offering for sale, selling, or importing for these purposes that product;

(b) where the subject matter of a Patent is a process, to prevent third parties not having the owner's consent from the act of using the process, and from the acts of: using, offering for sale, selling, or importing for these purposes at least the product obtained directly by that process.

2. Patent owners shall also have the right to assign, or transfer by succession, the Patent and to conclude licensing contracts.

Article 29 Conditions on Patent Applicants

1. Members shall require that an applicant for a Patent shall disclose the invention in a manner sufficiently clear and complete for the invention to be carried out by a person skilled in the art and may require the applicant to indicate the best mode for carrying out the invention known to the inventor at the filing date or, where priority is claimed, at the priority date of the application.

2. Members may require an applicant for a Patent to provide information concerning the applicant's corresponding foreign applications and grants.

Article 30 Exceptions to Rights Conferred, Members may provide limited exceptions to the exclusive rights conferred by a Patent, provided that such exceptions do not unreasonably conflict with a normal exploitation of the Patent and do not unreasonably prejudice the legitimate interests of the Patent owner, taking account of the legitimate interests of third parties.

\section{Patentability Invention}

Article 2 on Patent Law (2016) regulates the protection of Patents which includes simple Patents and Patents. Patent protection requirements are still the same as the previous law (2001) which is new, contains inventive steps, and can be applied in industry.

Article 4 of Patent Law also states that the invention does not cover: a) aesthetic creations; b) scheme; c) rules and methods for carrying out activities: (1) involving mental activities; (2) the game; and (3) business.; d) rules and methods that only contain computer programs; e) presentation of information; and f) findings (discovery) in the form of: (1) new uses for existing and/or known products; and/or (2) new forms of existing compounds which do not produce significant increases in efficacy and there are known differences in the chemical structure of compounds.

Rating of novelty according to the 'new' Qualifications based on Article 5, 2016 Patent Law, namely (1) the invention is considered new as referred to in Article 3 Paragraph (1) if on the Filing Date, the Invention is not the same as the technology previously disclosed; and (2) The technology disclosed previously as referred to in paragraph (1) is technology that has been announced in Indonesia or outside Indonesia in a written, oral description or through demonstration, use or other means that enables an expert to carry out the invention before Received Date; or the priority date in case the application is filed with Priority Rights; (3) The technology disclosed previously as 
referred to in paragraph (1) includes other Application documents submitted in Indonesia published on or after the Filing Date for which the substantive inspection is being carried out, but the Filing Date is earlier than the Filing Date or the priority date of the Request.

Article 6 Paragraph (1) states that the Invention shall not be deemed announced if within a period of 6 (six) months prior to the Filing Date, the Invention has: a) displayed in an official exhibition or in an exhibition that is recognized as an official exhibition, both held in Indonesia and abroad; b) used in Indonesia or abroad by its Inventor in the context of an experiment for research and development purposes; and/or; c) announced by the Inventor in: (1) a scientific session in the form of examinations and/or stages of a thesis examination, thesis, dissertation, or other scientific work; and/or; (2) other scientific forums in the context of discussing research results in educational institutions or research institutions.

Article 6 Patent Law is also not considered to have been announced if within 12 (twelve) months prior to the Filing Date, there are other parties who announce by violating the obligation to maintain the confidentiality of the invention.

Regarding inventive step, Article 7 of Patent Law states that the invention contains inventive steps if the said invention for someone who has certain expertise in the field of engineering is unpredictable and to determine an invention is unpredictable as referred to in Paragraph (1) must be done by taking into account the expertise that was at the time the application was submitted or that was already available at the time the first application was filed in the case that the application was submitted with priority rights. Likewise regarding industrial applicable it is stated in Article 8 that the invention can be applied in industry if the invention can be implemented in industry as described in the application.

Article 9 of Patent Law also states that inventions which cannot be granted Patents include: a) a process or product whose announcement, use or implementation is contrary to statutory regulations, religion, public order or morality; b) the method of examination, treatment, treatment and/or surgery applied to humans and/or animals; c) theories and methods in the fields of science and mathematics; d) living things, except micro-organisms; or; e) biological processes that are essential for producing plants or animals, except non biological processes or microbiological processes.

In order to accommodate the interests of protecting genetic resources/traditional knowledge, Article 26 of Patent Law states that if the invention relates to and/or comes from genetic resources and/or traditional knowledge, it must be clearly and correctly stated the origin of genetic resources and/or knowledge mentioned in the description. Information about genetic resources and/or traditional knowledge is determined by official institutions recognized by the government. Likewise, it is explicitly stated that the sharing of results and/or access to the utilization of genetic resources and/or traditional knowledge shall be carried out in accordance with the laws and international agreements in the field of genetic resources and traditional knowledge. This is in accordance with efforts to embrace local wisdom, by providing support for the growth and development of intellectual property inherited from ancestors, synergized with government alignments through regulation and law enforcement. A helping hand from various parties both related institutions, NGOs and the campus is certainly expected. 
Regarding the acquisition of Patent rights, legal subjects entitled to Patents based on Article 10 of Patent Law are as follows: (1) The party entitled to obtain a Patent is an Inventor or person who further receives the said inventor's rights; and (2) if the invention is produced jointly by several people, the right to the invention is jointly owned by the relevant inventors.

Furthermore Article 1, unless it is proven otherwise, the party considered as an inventor is a person or persons who are first stated as inventors in an Application. As is the case with the study of the doctrine of shop's right, Article 12 of Patent Law also holds that the Patent holder of an invention produced by an inventor in a work relationship is the party providing the work, unless otherwise agreed. This provision also applies to inventions produced, both by employees and workers who use data and/or facilities available in their work. It should be underlined that from now on it is clear and unequivocal, the inventor is entitled to receive compensation based on the agreement made by the employer and the Inventor, taking into account the economic benefits obtained from the said invention. The intended benefits can be paid based on: a) certain amount and all at once; b) percentage; c) a combination of a certain amount and all at once with prizes or bonuses; or d) other forms agreed by the parties.

Likewise, it was emphasized through Article 13 of Patent Law concerning who is entitled to a Patent in official relations and inventions in return to inventors related to their inventions after the invention is commercialized, as follows: (1) Patent holders of inventions produced by the inventor in official relations with government agencies are the said government agencies and inventors, unless otherwise agreed; (2) After a Patent has been commercialized, the inventor as referred to in Paragraph (1) has the right to obtain Rewards for the Patents that he produces from non-tax state revenue sources; (3) In the event that a government agency as a Patent Holder cannot implement his Patent, the inventor with the approval of the Patent Holder may implement the Patent with a third party; (4) With respect to the use of Patents as referred to in Paragraph (3), in addition to the Patent holder, the inventor receives royalties from third parties who obtain economic benefits from the commercialization of the Patent; (5) The provisions referred to in Paragraph (1) and Paragraph (2) do not nullify the right of the inventor to keep his name on the Patent certificate.

Regarding the period of Patent protection, it is still the same as the 2001 Paten Law, which is 20 years and cannot be extended further, based on Article 22 of the 2016 Patent Law the start and end date of the Patent period is recorded and announced through electronic media and/or non-electronic media. Article 23 states that simple Patent protection is granted for a period of 10 (ten) years from the Filing Date and cannot be extended. Regarding the requirements and procedure for application based on Article 24 of Patent Law, the application is submitted by the applicant or his Proxy to the Minister in writing in Indonesian language by paying a fee, submitted for one Invention or several Inventions which constitute an interconnected Invention unit, as well as applications can be submitted both electronically and non-electronically. Article 25 of the Patent Law regulates what must be written in the petition to contain at least: a) Date, month and year of application; b) Name, full address, and citizenship of the Inventor; c) the name, complete address, and nationality of the Applicant in the case that the Applicant is not a legal entity; d) full name and address of the applicant if the applicant is a legal entity; e) name, and complete address of the Power of Attorney if 
the Application is submitted through a Proxy; and f) the name of the country and the Filing Date for the first Application if the Application is filed with Priority Rights.

The application must be accompanied by: a) title of Invention; b) a description of the invention; c) claims or claims of inventions; d) abstract of the invention; e) drawings mentioned in the description required to clarify the invention, if the application is accompanied by a picture; f) power of attorney if the application is filed through a Proxy; g) a statement of ownership of the invention by the Inventor; h) letter of transfer of ownership rights of the Invention if the Application is submitted by an Applicant who is not the Inventor; and i) evidence of deposit of microorganisms in the case of an Application related to microorganisms.

Likewise the description of the Invention must reveal clearly and completely about how the Invention can be carried out by a person skilled in the art, more importantly the Claim must disclose clearly and consistently the core of the Invention. Claims should not be blurred or ambiguous.

Concerning substantive announcements and examinations, it is regulated in Article 4653 of the Patent Law that the Minister announces requests that have fulfilled the provisions, carried out no later than 7 (seven) days after 18 (eighteen) months from the Filing Date; or priority date if the application is filed with Priority Rights. The announcement is made through electronic media and/or non-electronic media, the date the announcement of the application is recorded by the Minister and the announcement must be seen and accessed by everyone. The announcement is valid for 6 (six) months from the date of the announcement of the Application, made by including: a) name and citizenship of the inventor; b) the full name and address of the Applicant and the Proxy in the case that the Application is filed through a Proxy; c) Title of Invention; d) the Filing Date or priority date, number and country where the Application was first filed in the case that the Application is filed with Priority Rights; e) abstract of the invention; f) classification of inventions; g) drawings, if the application is attached with drawings; h) announcement number; and i) Application number.

Application for substantive examination in accordance with Article 51 of the Patent Law is submitted in writing no later than 36 (thirty six) months from the date of Receipt to the Minister with a fee and if the request for substantive examination is not submitted within the time limit or the fee for it is not paid, the application is deemed withdrawn back. The Minister then notifies the applicant or his attorney in writing of the application deemed withdrawn. If the request for a substantive examination is submitted before the end of the announcement period, the substantive examination shall be carried out after the end of the announcement period, but if the request for a substantive examination is submitted after the end of the announcement period, the substantive examination shall be carried out after the date of receipt of the request for the substantive examination.

Requests for substantive examination of divisional applications or amendments to requests from Patents to simple Patents or vice versa must be filed together with the divisional submission of applications or amendments to applications from Patents to Patents simple or vice versa, so if a request for substantive examination is not submitted together with divisional applications or amendments to requests from 
Patents to a simple Patent or vice versa, the divisional application or amendment of an application from a Patent to a simple Patent or vice versa is deemed withdrawn.

Article 53 states: (1) Substantive examination is carried out by the examiner. (2) The Minister may request expert assistance and/or use the facilities required from other agencies for the purpose of substantive examination. (3) The expert as referred to in Paragraph (2) is appointed and dismissed by the Minister. (4) The results of the substantive examination carried out by experts referred to in paragraph (3) are considered to be the same as the results of the examination carried out by the Examiner. (5) The results of the inspection referred to in paragraph (4) must obtain approval from the Minister. (6) Further provisions regarding the procedures and conditions for appointment and dismissal of experts as referred to in Paragraph (3) shall be regulated by Ministerial Regulation.

If the application for a Patent uses priority rights, then in accordance with Article 55 of the 2016 Patent Law the Minister may request the Applicant and/or the Patent office in the country of origin of Priority Rights or in other countries regarding the completeness of documents in the form of: a) valid copies of letters relating to the results of a substantive examination conducted for the first Patent application abroad; b) valid copies of Patent documents that have been granted in connection with a Patent application for the first time abroad; c) a valid copy of the decision concerning the rejection of a Patent application that was first abroad, if the Patent application is rejected; d) a valid copy of the decision to abolish a Patent that has been issued abroad if the Patent has been written off; and/or; e) other documents required.

Actually, if viewing the justification for granting a Patent, in addition to rewarding the inventor, of course the intention (social moral) is given this Patent so that every invention is opened to the public interest, for the benefit of society and technological development. As mentioned in the previous paragraph, by opening a new discovery it provides the information needed for further technological development based on the discovery and to give guidance to those who are interested in exploiting the invention. Besides, if there are people who want to do own Patent research because of research is a challenging and fun experience. The Patent registration system in Indonesia adheres to first to file (who first registered), in contrast to the Patent registration system in America which previously is first to invent (who first discovered and completed the discovery). However, the United States has revised the system after enactment a new law in 2013 that changed the system from first to inventory (FTI) to first to file (FTF).

\subsubsection{In Japan}

"In June 2013, the Japanese Cabinet approved the "Japan Revitalization Strategy" and the "Basic Principles Concerning IP Policy," aiming at becoming the most advanced IPbased nation in the next decade. In order to ensure the successful implementation of these policies, the Government had promptly reformed various systems as well as improved human resource capabilities, which will further promote the creation, protection and strategic use of IP."17

17 JPO (Japan Patent Office). Outline of the Partial Revision of the Patent Act, etc. https://www.jpo.go.jp/e/system/laws/rule/hokaisei/document/tokkyohoutou_kaiei_260514/outline.p df 


\section{Here the Outline of the Act:}

"In light of the global momentum to harmonize international IP systems, the Government of Japan is systematically developing the foundations of its IP system through revising its laws such as its Patent Act and Patent Attorney Act. Based on the revised Patent Act, relief measures will be enhanced; and a new system that will enable applicants to submit oppositions to granted Patents will be created. And the revised Patent Attorney Act more precisely clarify the roles and responsibilities of Patent attorneys and also increase the scope of the services they are able to provide."18

The Revision of the Patent Act also asserts that the Government has to "Enhance Relief Measures. In line with overseas legal systems, the Patent Law is to be revised to take relief measures so that applicants are entitled to extend certain periods required for filing, examination, and other procedures due to exceptional unavoidable circumstances such as disasters." 19

Regarding the acquisition of Patent rights in Japan, it is explicitly disclosed in the Patent Law (Law No. 121 of 1959) which has been revised in Law No. 36 of 2014 (which became effective on April 1, 2015. Article 39 (1) states, "Where two or more Patent applications claiming identical inventions have been filed on different dates, only the applicant who filed the Patent application on the earliest date The statement above clearly states that Japan uses the First to File (FTF) system, not the First to Invent (FTI).

In the Petition, the Japan Patent Office will see the invention with "Novelty" contained in the Article 29 (1) Patent Law which has the right to obtain recognition for its discovery, except in the following cases:

"Any person who has made an invention which is industrially applicable may obtain a Patent therefor, except in the case of the following inventions: (i) inventions that were publicly known in Japan prior to the filing of the Patent application; (ii) inventions that were publicly worked in Japan prior to the filing of the Patent application; or (iii) inventions that were described in distributed publication in Japan or a foreign country prior to the filing of the Patent application."

Japanese Patent Law grants Patents from inventions which occur when people find their inventions on the basis of measuring "natural persons (not an artificial person such as a business entity)" as the inventor. This also applies to employees who find what is known as an "employee invention", for example new inventions made by employees in the context of their obligations in labor regulations (Article 35, Paragraph 1 of the Patent Law). Inventions can be made, by filing a Patent application by someone with expertise in art, limited to someone with the usual ability as a basis for measuring inventions made into new discoveries.

The Japanese government revises employee Patent regulations granted to companies in the form of non-exclusive licenses raising the issue of remuneration for employees who collaborate to find them in the Article 35 Patent Law of:

"An employer, a legal entity or a state or local public entity (hereinafter referred to as the "employer, etc." shall have a non-exclusive license on the Patent right concerned, where an employee, an executive officer of a legal entity or a national or local public

18 Ibid.

19 Ibid. 
official (hereinafter referred to as the "employee, etc.") has obtained a Patent for an invention which by reason of its nature falls within the scope of the business of the employer, etc. and an act or acts resulting in the invention were part of the present or past duties of the employee, etc. performed on behalf of the employer, etc. (hereinafter referred to as an "employee invention") or where a successor in title to the right to obtain a Patent for an employee invention has obtained a Patent therefor:."

As for the new regulation, the employer can make a contract for the inventor's employee, but this new regulation can trigger excessive authority over the employee's invention. The statement of "reasonable profit" obtained by workers who carry out inventive guidelines must be made by the Minister of Economy, Trade and Industry (METI), how much the standard distribution of benefits.

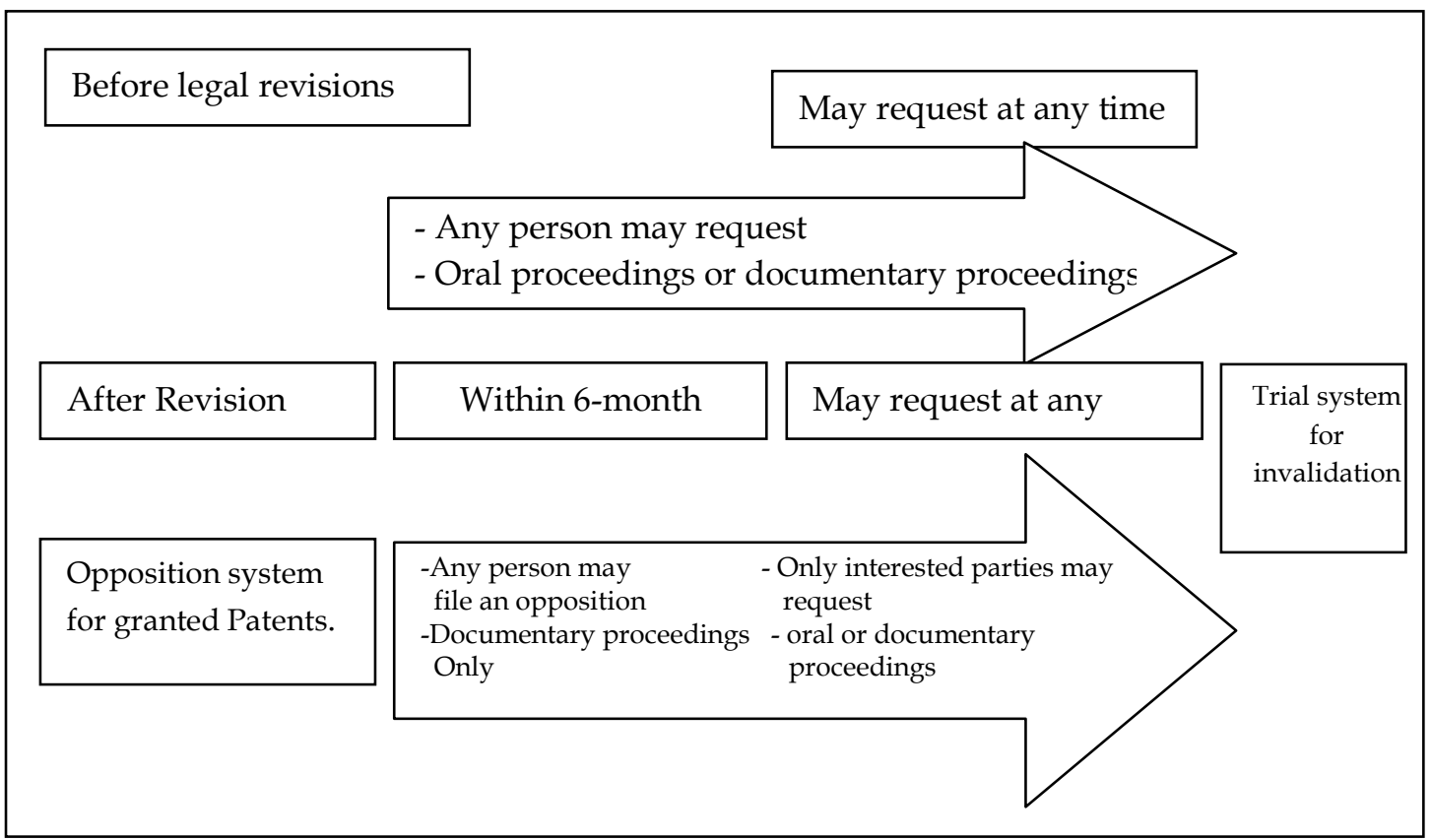

Figure 1. Revision of the Patent Act.

Source: https://www.jpo.go.jp

"With the Digital Revolution, dissolving walls between industries to make way for open innovation now is the moment for SMEs and ventures to wield their outstanding technologies as a tool for major growth. Japan's litigation system will be upgraded so that the Patents that companies have strived to acquire can play their proper role in protecting prized technologies." 20

"Patent infringement characteristics: a) Patents easily infringed (publicly disclosed; no need for physical theft). b) difficult to prove (evidence tends to reside with the infringer), c) difficult to deter (no criminal case). Need to prevent an "infringer wins" situation." 21

20 JPO (Japan Patent Office). Review of the Patent Litigation System.

https://www.jpo.go.jp/system/laws/rule/hokaisei/tokkyo/document/tokkyohoutou_kaiei_r010517/07 .pdf

${ }^{21}$ Ibid. 


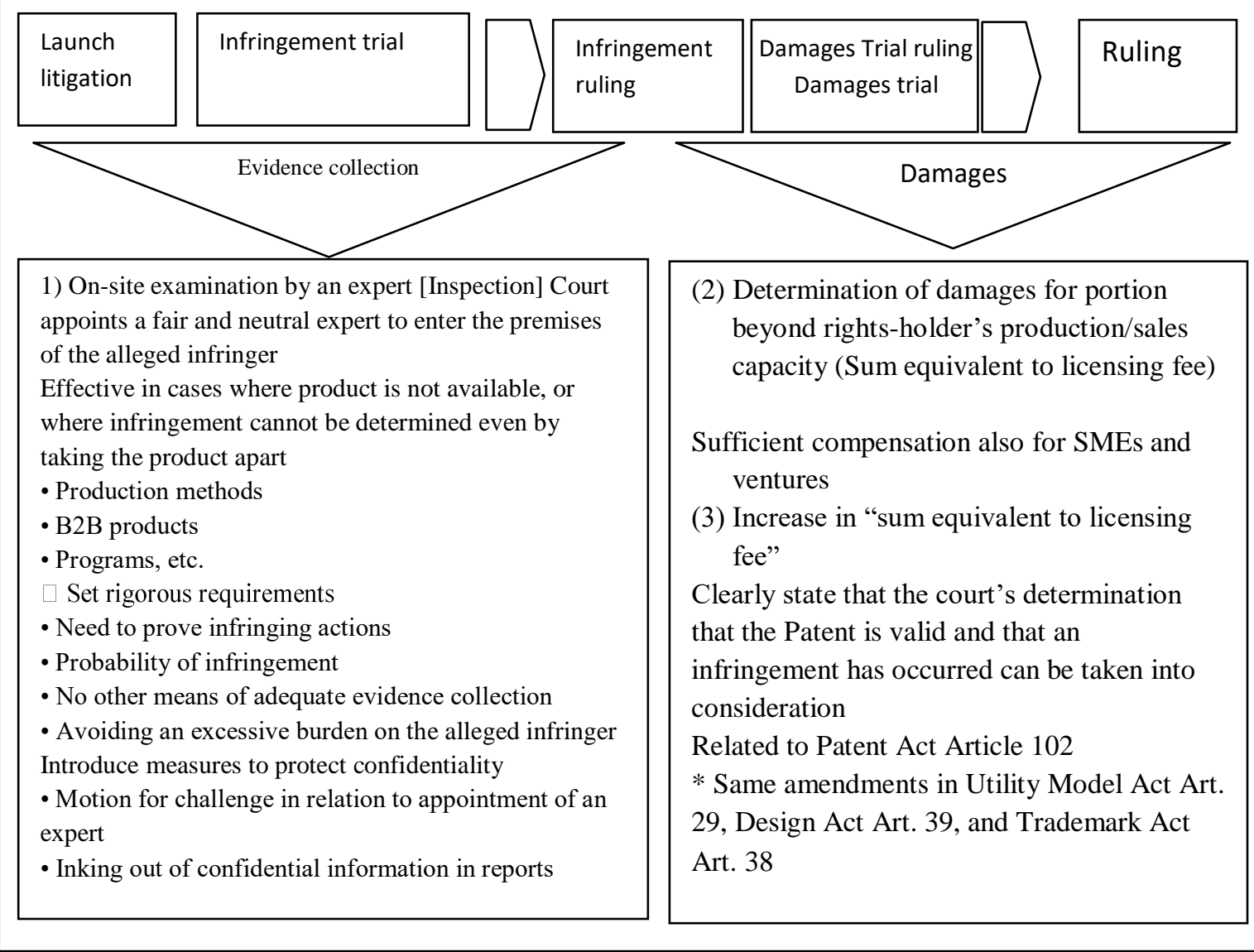

Figure 2. Patent Infringement Characteristics

Source: https://www.jpo.go.jp

\section{The Law on the Partial Revision}

"The Law on the Partial Revision of the Patent Law and Other Law (Law No. 3 2019). The Law on the Partial Revision of the Patent Law and Other Law (Law No. 36 of 2014), which was passed on April 25, 2014, and promulgated on May 14, 2014, entered into force on April 1, 2015. It amends the Patent Law, the Design Law, the Trademark Law, the Patent Attorney Law and the Law on the International Applications under the Patent Cooperation Treaty (PCT) in order to: (i) enhance relief measures for applicants and create new opposition system for Patent rights; (ii) set out provisions for simultaneously filing a design application in multiple countries to comply with the Geneva (1999) Law of the Hague Agreement Concerning the International Registration of Industrial Designs to which Japan acceded on May 13, 2015; (iii) expand the scope of protection to non-conventional trademarks such as color marks, sound marks, hologram marks, motion marks, and position marks already protected in some countries, and expand the scope of eligible entities to register regional collective trademarks; (iv) clarify Patent attorney's missions and expand the scope of their 
business; and (v) simplify payment procedures for fees for international applications under the PCT." 22

\subsubsection{In America}

A study revealed that the division of US labor over the past 65 years has made intellectual property product capital (IPP) fully responsible for the observed decline in the US labor market share which is constantly on the contrary for capital structure and equipment. This explains that the US is undergoing a transition to a more IPP capital intensive economy. ${ }^{23}$

The law has shifted the US Patent system from "the first find" or FTI to the "first to invent" or FTF from the system, eliminating the interference process, and developing post-grant opposition. The main provisions come into force on September 16, 2012 and on March 16, 2013.

As for the U.S. Patent Code, 35 U.S.C. § 102 mentioned:

"A Patent for may not be obtained, though the invention is not identically disclosed or described as set forth in section 102, if the differences between the subject matter sought to be Patented and the prior art are such that the subject matter as a whole would have been obvious at the time the invention was made to a person having ordinary skill in the art to which said subject matter pertains. Patentability shall not be negated by the manner in which the invention was made."

This regulation shows that America follows FTF because the discovery must be registered first. The inventive step is explained by the difference between the subject matter of the Patented invention and the prior art, which refers to "non-obvious", which is different from someone who has ordinary expertise in his art.

Someone may get a Patent based on 35 U.S. Code $\S 102$ - Conditions for Patentability; novelty must meet the following requirements:

(a) NOVELTY; PRIOR ART - A person shall be entitled to a Patent unless -

(1) the claimed invention was Patented, described in a printed publication, or in public use, on sale, or otherwise available to the public before the effective filing date of the claimed invention; or

(2) the claimed invention was described in a Patent issued under section 151, or in an application for Patent published or deemed published under section 122(b), in which the Patent or application, as the case may be, names another inventor and was effectively filed before the effective filing date of the claimed invention.

As such, acknowledgment of "novelty" and "prior art" cannot be accepted because the findings have been printed, used or sold before registration. In addition, the discovery is also not acceptable because other people have registered before the object.

The discovery must also meet "non-obviousness" which in the "inventive step" has found the difference between novelty or "novelty" and "prior art" or previous findings

22 JPO (Japan Patent Office). The Act on the Partial Revision of the Patent Act and Other Acts (Act No. 3 of May 17, 2019). https://www.jpo.go.jp/e/system/laws/rule/hokaisei/tokkyohoutou_kaiei_20190517.html

${ }^{23}$ Koh, D., Santaeul'alia-Llopis, R., \& Zheng, Y. (2016). Labor Share Decline and Intellectual Property Products Capital. American Economic Association, 29 (February), p. 1. http://r-santaeulalia.net/pdfs/IPPand-USLaborShare-short.pdf. 
in accordance with the statement in U.S. Patent Code, 35 U.S.C. § 102 which states the three concepts above.

The scope of Patent protection according to Patent Positive Law in Japan, the United States and Indonesia has so far followed the development of TRIPs and WTO, with the same qualification of Patentability invention Patents namely novelty, non-obviousness steps and industrial applicable. Indonesia and Japan have the same acquisition system which is first to file, America previously used first to inventory, but then in 2013 it changed to first to file. Coverage of protection remains the same in the fields of technology and industry.

\section{Exceptions}

(1) Disclosures made 1 year or less before the effective filing date of the claimed invention: a disclosure made 1 year or less before the effective filing date of a claimed invention shall not be prior art to the claimed invention under subsection (a) (1) if:

(A) the disclosure was made by the inventor or joint inventor or by another who obtained the subject matter disclosed directly or indirectly from the inventor or a joint inventor; or

(B) the subject matter disclosed had, before such disclosure, been publicly disclosed by the inventor or a joint inventor or another who obtained the subject matter disclosed directly or indirectly from the inventor or a joint inventor. ${ }^{24}$

(2) Disclosures appearing in application and Patents. A disclosure shall not be prior art to a claimed invention under subsection (a) (2) if:

(a) the subject matter disclosed was obtained directly or indirectly from the inventor or a joint inventor;

(b) the subject matter disclosed had, before such subject matter was effectively filed under subsection (a) (2), been publicly disclosed by the inventor or a joint inventor or another who obtained the subject matter disclosed directly or indirectly from the inventor or a joint inventor; or

(c) the subject matter disclosed and the claimed invention, not later than the effective filing date of the claimed invention, were owned by the same person or subject to an obligation of assignment to the same person. ${ }^{25}$

\section{Common Ownership under Research Agreements}

Subject matter disclosed and a claimed invention shall be deemed to have been owned by the same person or subject to an obligation of assignment to the same person in applying the provisions of subsection (b) (2) (C) if:

\footnotetext{
24 USPTO (United States Patent and Trademark Office). Use of Affidavits or Declarations Under 37 CFR 1.130 To Overcome Prior Art Rejections [R-07.2015]. https://www.uspto.gov/web/offices/pac/mpep/s2155.html

${ }^{25}$ USPTO (United States Patent and Trademark Office). Laws, Regulations, Policies, Procedures, Guidance and Training. https://www.uspto.gov/patent/laws-regulations-policies-procedures-guidanceand-training
} 
(1) the subject matter disclosed was developed and the claimed invention was made by, or on behalf of, 1 or more parties to a joint research agreement that was in effect on or before the effective filing date of the claimed invention;

(2) the claimed invention was made as a result of activities undertaken within the scope of the joint research agreement; and

(3) the application for Patent for the claimed invention discloses or is amended to disclose the names of the parties to the joint research agreement. ${ }^{26}$

\section{Patents and Published Applications Effective as Prior Art}

For purposes of determining whether a Patent or application for Patent is prior art to a claimed invention under subsection (a) (2), such Patent or application shall be considered to have been effectively filed, with respect to any subject matter described in the Patent or application:

(1) if Paragraph (2) does not apply, as of the actual filing date of the Patent or the application for Patent; or

(2) if the Patent or application for Patent is entitled to claim a right of priority under Articles 119, 365(a), 365(b), 386(a), or 386(b), or to claim the benefit of an earlier filing date under Articles 120, 121, 365(c), or 386(c), based upon 1 or more prior filed applications for Patent, as of the filing date of the earliest such application that describes the subject matter. ${ }^{27}$

\subsection{Patent law enforcement in Japan, America and Indonesia}

\subsubsection{In Indonesia}

In the Indonesian Patent Law there is an Appeals Commission which is essentially processing a legal settlement against a refusal of an Application. Then if there is a dispute (Patent case) then it is settled in the PN (Commercial Court). This litigation is regulated in Articles 142-152 of the Patent Law of the entitled party/Patent subject listed in Articles 10-13 of the Patent Law can be sued to the Commercial Court if a Patent is granted to someone other than the rightful party. The Appeals Commission is regulated in Articles 64-70. In the 2016 Patent Law the tasks/roles of the Patent Appeal Commission (Article 64) are: (1) The Patent Appeal Commission has the duty to accept, examine and decide: a) appeal against the Application; b) appeal for correction of the description, claim and/or picture after the Application has been granted a Patent; and c) appeal against the decision to grant a Patent. (2) The composition of the Patent Appeal Commission consists of: a) 1 (one) chairman and member; b) 1 (one) vice chairman and member; and c) at most 30 (thirty) members who come from the elements: (1) 15 (fifteen) experts in the field of Patents; and (2) 15 (fifteen) Examiners. (3) Members of the Patent Appeal Commission as referred to in paragraph (2) are appointed and dismissed by the Minister for a term of 3 (three) years and may be reappointed for 1 (one) subsequent term. (4) The Chairperson and Deputy Chairperson are elected from and by members of the Patent Appeal Commission.

Furthermore Article 65 of the 2016 Patent Law states that to examine appeals, the Patent Appeal Commission forms an odd number of assemblies of at least 3 (three) people and at most 5 (five) people, one of whom is designated as chairman. The

\footnotetext{
${ }^{26} \mathrm{Ibid}$.

${ }^{27}$ Ibid.
} 
Assembly as referred to in Paragraph (1) originates from a member of the Patent Appeal Commission whose member is the Inspector with the lowest position of the Intermediate Examiner who does not conduct a substantive examination of the Application. In the case of the Assembly amounting to more than 3 (three) people, the Examiner as referred to in Paragraph (1) shall be fewer than the members of the Assembly other than the Examiner.

The Appeal (Article 67) may be filed against the refusal of the Application; correction of descriptions, claims and/or drawings after the Application has been granted a Patent; and/or decision to award a Patent. Article 68 states that an appeal is filed in writing, it is submitted no later than 3 (three) months from the date of sending the notice of rejection of the application, and the reason for the appeal is not a new reason or explanation that expands the scope of the invention.

Related to the appeal for Corrections of Description, Claims, and/or Drawings after the Patent Application is stated in Articles 69-70 as follows:

(1) An application for an appeal against a correction of a description, claim, and/or picture after the application has been granted a Patent shall be submitted within a period of 3 (three) months from the date the notification letter can be granted a Patent.

(2) If the Petitioner or his Proxy submits an appeal after the time period referred to in paragraph (1), the Petitioner cannot re-submit the appeal request.

(3) The Patent Appeal Commission shall begin examining an appeal for correction of the description, claim, and/or picture after the Application has been granted a Patent within a maximum of 1 (one) month from the date of receipt of the appeal

(4) Corrections as referred to in paragraph (1) must be limited to the following matters: a) limitation of the scope of claims; b) error correction in the translation of the description; and/or; c) clarification of the contents of the description that is unclear or ambiguous.

(5) The correction referred to in paragraph (4) does not result in the scope of the invention protection being broader than the scope of the invention protection which was first submitted.

(6) Decisions of the Patent Appeal Commission shall be made no later than 6 (six) months from the date of the commencement of the examination of the application for appeal as referred to in Paragraph (3).

(7) In the event that the Patent Appeal Commission decides to accept an appeal for correction of the description, claims and/or drawings after the Application has been granted a Patent, the Minister will follow up by changing the certificate attachment.

(8) In the case of an appeal for correction of the description, claims and/or drawings received as referred to in Paragraph (7), the Minister shall record and announce them through electronic media and/or non-electronic media.

Appeal for Decision on Granting a Patent in accordance with Article 70 of the 2016 Patent Law; an appeal for a decision on the award of a Patent shall be submitted in writing by the interested party or its Proxy to the Patent Appeal Commission with a copy delivered to the Minister with a fee. An appeal for a decision on the award of a 
Patent shall be filed within a period of 9 (nine) months at the latest from the date the notification is granted Patent. If an appeal against the decision to grant a Patent that has been given to a Patent Holder is submitted beyond the time period of the interested party or his Proxy can take legal action by filing a lawsuit with the Commercial Court. The Patent Appeal Commission shall begin examining an appeal against the decision to grant a Patent no later than 1 (one) month from the date of receipt of the appeal.

An appeal against the decision to grant a Patent as referred to must be explained in full with the objections and reasons complete with strong supporting evidence. The decision of the Patent Appeal Commission is stipulated no later than 9 (nine) months from the date of the commencement of the appeal hearing. In the event that the Patent Appeal Commission approves part of the appeal against the decision to grant a Patent, the Minister follows up by amending the certificate attachment. In the event that the Patent Appeal Commission approves the entire contents of the appeal request against the decision to grant a Patent, the Minister revokes the certificate. Regarding the decision of the Patent Appeal Commission, the Minister records and announces it through electronic media and/or non-electronic media.

\subsubsection{In Japan}

In Japanese Patent Regulations, the Patent Law (Law No. 121 of 1959) which has been revised in Law No. 36 of 2014 (which became effective on April 1, 2015, states that a person who submits a Patent application to the Japan Patent Office (JPO), if rejected, can submit an "appeal", Article 121 (1) states it as follows: A person who has received an examiner's decision to the effect that an application is to be refused and is dissatisfied may file appeals against the examiner's decision of refusal within three months from the date the certified copy of the examiner's decision has been served.

That person will make an "invalidation" through the "trial" and "appeal" departments. The "invalidation" of Patents can be done because other parties who have Patents can be submitted for validity through a "trial" or court, which is regulated in Article 123 (1) which states, "Where a Patent falls under any of the following, a request for invalidation trial may be filed. In the event of two or more claims, a request for invalidation trial may be filed for each claim".

In addition, someone who has a Patent can file a lawsuit in the district court for violations. If the decision is not satisfactory, he can appeal to the High Court and Supreme Court.

\subsubsection{In America}

While Patent law enforcement can be done through Federal courts in America and an administrative body known as "The US Patent Office (USPTO)". The USPTO is an administrative body entrusted with examining and issuing Patents. If the person applying for a Patent has been rejected a second time, listed in Article 35 U.S.C. 134 which states that he can submit "Patent trial" and "appeal board":

(a) PATENT APPLICANT.-An applicant for a Patent, any of whose claims has been twice rejected, may appeal from the decision of the primary examiner to the Patent Trial and Appeal Board, having once paid the fee for such appeal.

(b) PATENT OWNER. - A Patent owner in a reexamination may appeal from the final rejection of any claim by the primary examiner to the Patent Trial and Appeal Board, having once paid the fee for such appeal. 
(c) THIRD-PARTY. - A third-party requester in an inter parties proceeding may appeal to the Board of Patent Appeals and Interferences from the final decision of the primary examiner favorable to the Patentability of any original or proposed amended or new claim of a Patent, having once paid the fee for such appeal.

The Patent holder (owner) can make a claim to the Federal court for claims that have been owned by another party, which has been regulated in 35 U.S.C. 315. Thus Patent applications, Patent retesting, and third party applications for appeal, Indonesia, Japan and the United States have provided broader law enforcement to obtain Patents, both departments and ordinary courts.

\section{Conclusion}

The scope of Patent protection according to Patent Law in Indonesia, Japan, and America has so far followed the development of TRIPs and WTO, with the same qualifications for Patentability invention inventions namely novelty, nonobviousness/inventive steps and industrial applicable. For the time being, Indonesia, Japan and the US have the same acquisition system, namely "first to file". Coverage of protection remains the same in the fields of technology and industry, but Japan extends the scope of Patents to cover those produced by the employees and Indonesia also adopts this model. In term of enforcement, Indonesian Patent law also develops a new appeal commission to settle Patent disputes.

Nowadays, Patent Law in Indonesia, Japan, and America should always follow the development of TRIPs and WTO. The enforcement of Patent law in Patent Positive law should take precedence over the appeal commission rather than through the Court.

\section{Acknowledgments}

The research was funded and facilitated by YARSI University and several related local governments. To that end, the authors convey their gratitude and appreciation to the Directorate General of Ministries of Research, Technology, and Higher Education, YARSI University.

\section{References}

Books:

Aplin, T. \& Davis, J. (2013). Intellectual Property Law, Text, Cases and Materials (2nd ed.). Oxford University Press.

Bakhri, S. (2012). Beban Pembuktian. Gramata.

Barnes, A. J., Dworkin, T. M., \& Richards, E. (2012). Law for Business. Mc.Graw Hill Irwin.

Blair, R. D. \& Cotter, T. F. (2005). Intellectual Property, Economic and Legal Dimensions of Rights and Remedies ( $1^{\text {st }}$ ed.). Cambridge University Press.

Drahos, P. (2016). A Philosophy of Intellectual Property (1 ${ }^{\text {st }}$ ed.). The Australian National University, Canberra. https:// doi.org/10.4324/9781315263786 
Emanuel, S. L. (2013). Corporations and Other Business Entities. Wolters Kluwer Law \& Business.

Firdausy, C. M. (2009). Iptek Tidak Hanya di Tangan Pemimpin. In Sain dan Teknologi. PT Gramedia Pustaka Utama.

Friedmann, L. (2002). Law in America: A Short History. Modern Library Chronicles Book.

Gibbs, A. \& DeMatteis, B. (2003). Essentials of Patents. John Wiley \& Sons, Inc.

Hariyani, I. (2010). Prodedur Mengurus HAKI yang Benar. Pustaka Yustisia.

Howe, H. R. (2013). Property, Sustainability and Patent Law could the Stewardship Model facilitate the promotion of green technology? in Concepts of Property in Intellectual Property Law. Cambridge University Press

Lakitan, B. (2009). Teknologi Berorientasi Domestik. In Sain dan Teknologi. PT Gramedia Pustaka Utama.

Lewis, A. (2012). Dasar-Dasar Hukum Bisnis. Nusa Media.

Marzuki, P. M. (2007). Penelitian Hukum. Kencana.

Mertokusumo, S. (2006). Penemuan Hukum. Liberty.

Purwaningsih, E. (2015). Hukum Paten. Mandar Maju.

Rifai, A. (2010). Pen Rowland, D., Kohl, U., \& Charlesworth. (2012). The 'As Such Exclusion, Patents and Computer Software. In Information Technology Law (4 ${ }^{\text {th }}$ ed.). Routledge.

Saidin, O. K. (2010). Aspek Hukum Hak Kekayaan Intelektual (7th ed.). PT. RajaGrafindo Persada.

Saleh, M. (2011). Penerapan asas Peradilan. Graha Cendekia.

Soekanto, S. (2011), Faktor-Faktor yang Mempengaruhi Penegakan Hukum. PT. RajaGrafindo Persada.

Susanti, D.O. \& Efendi, A. (2005). Penelitian Hukum (Legal Research) (2nd ed.). Sinar Grafika.

\section{Journal Articles:}

Daulay, Z. (2012). Konsep Perlindungan Hukum terhadap Pengetahuan Tradisional Masyarakat Asli Tentang Obat di Indonesia. Jurnal Media Hukum, 19(2), 181-193.

Duffy, J. F., \& Hynes, R. (2016). Statutory Domain and The Commercial Law of Intelectual Property. Virginia Law Review, 102(1), 1-77. https:// papers.ssrn.com/sol3/papers.cfm?abstract_id=2599074

Gans, J. S., Murray, F. E., \& Stern, S. (2017). Contracting Over the Disclosure of Scientific Knowledge: Intellectual Property and Academic Publication. Research Policy, 46(4), 820-835. https://doi.org/10.1016/j.respol.2017.02.005

Gürkaynak, G., Yılmaz, İ., Yeşilaltay, B., \& Bengi, B. (2018). Intellectual Property Law and Practice in the Blochain Realm. Computer Law \& Security Review, 34(4), 847862. https://doi.org/10.1016/j.clsr.2018.05.027 
Koh, D., Santaeul 'alia-Llopis, R., \& Zheng, Y. (2016). Labor Share Decline and Intellectual Property Products Capital. American Economic Association, 29 (February), 1-27. http://r-santaeulalia.net/pdfs/IPP-and-USLaborShareshort.pdf

Lee, E. M. \& May, D. C. (2016). Computer Assisted and/or Implemented Process and System for Annotating and/or Linking Documents and Data, Optionally in an Intellectual Property Management System. United States Patent, 9.460.414, 1-45. https://patents.google.com/patent/US9460414B2/en

O'Melinn, L. (2015). Property without Bounds and the Mythology of Common Law Copyright, Special Issues: Thinking and Rethingking Intellectual Property, Studies in Law, Politics and Society. Emerald Group Publishing Limited, 67, p. 75117. https://doi.org/10.1108/S1059-433720150000067004

Rohaini. (2018). The Madrid Protocol: Mewujudkan Perlindungan Hukum yang Efektif Bagi Merek Terkenal di ASEAN. Jurnal Media Hukum, 25(1), 68-80.

\section{Internet:}

JPO (Japan Patent Office). Enhancement of the patent litigation system. https://www.jpo.go.jp/system/laws/rule/hokaisei/tokkyo/document/tokkyo houtou_kaiei_r010517/07.pdf

JPO (Japan Patent Office). Outline of the Partial Revision of the Patent Act, etc. https://www.jpo.go.jp/e/system/laws/rule/hokaisei/document/tokkyohouto u_kaiei_260514/outline.pdf

JPO (Japan Patent Office). Review of the Patent Litigation System. https://www.jpo.go.jp/system/laws/rule/hokaisei/tokkyo/document/tokkyo houtou_kaiei_r010517/07.pdf

JPO (Japan Patent Office). The Act on the Partial Revision of the Patent Act and Other Acts (Act No. 3 of May 17, 2019).

https://www.jpo.go.jp/e/system/laws/rule/hokaisei/tokkyohoutou_kaiei_201 90517.html

USPTO (United States Patent and Trademark Office). Laws, Regulations, Policies, Procedures, Guidance and Training. https://www.uspto.gov/patent/lawsregulations-policies-procedures-guidance-and-training

USPTO (United States Patent and Trademark Office). Use of Affidavits or Declarations Under 37 CFR 1.130 To Overcome Prior Art Rejections [R-07.2015]. https://www.uspto.gov/web/offices/pac/mpep/s2155.html

USPTO (United States Patent and Trademark Office). United States Code Title 35 Patent. www.uspto.gov [Accessed April 11, 2017].

\section{Regulations:}

WIPO. (1997). Agreement Between The World Intellectual Property Organization and The WTO (1995) and TRIPs Agreement (1994), Geneva. https://www.wipo.int/edocs/pubdocs/en/wipo_pub_223.pdf 